\title{
Cave Associated Infection: An Issue in Tropical Medicine
}

\author{
Viroj Wiwanitkit, M.D. ${ }^{1-5}$
}

${ }^{1}$ Honorary professor, Dr DY Patil University, Pune, India; ${ }^{2}$ Visiting professor, Hainan Medical University, China;

${ }^{3}$ Visiting professor, Faculty of Medicine, University of Nis, Serbia; ${ }^{4}$ Adjunct professor, Joseph Ayobabalola University, Nigeria; ${ }^{5}$ Special lecturer, Chulalongkorn University, Pathum Wan, Bangkok 10330, Thailand.

Received 10 July 2018 • Accepted 16 July 2018 • Published online 15 August 2018

\section{Abstract:}

Caves are interesting and attractive natural sites that visitors can enter and explore. Sometimes, the visitors come in contact with pathogens in the cave, resulting in cave associated infections. In this short article, the authors hereby summarize and discuss cave associated infections with special reference to tropical countries. There are many possible cave associated infections, such as histoplasmosis and rabies, which are considered serious health problems.

Keywords: cave, infection, medicine

Contact: Prof. Viroj Wiwanitkit, M.D. ${ }^{1-5}$

${ }^{1}$ Honorary professor, Dr DY Patil University, Pune, India; ${ }^{2}$ Visiting professor, Hainan Medical University, China; ${ }^{3}$ Visiting professor, Faculty of Medicine, University of Nis, Serbia; ${ }^{4}$ Adjunct professor, Joseph Ayobabalola University, Nigeria; ${ }^{5}$ Special lecturer, Chulalongkorn University, Pathum Wan, Bangkok 10330, Thailand.

E-mail: wviroj@yahoo.com
J Health Sci Med Res 2018;36(3):167-170 DOI: http://dx.doi.org/10.31584/jhsmr.2018.36.3.14

www.jhsmr.org 


\section{Introduction}

Many caves are very popular and therefore several tourists go into these caves each year. The health of the visitors entering the cave is an interesting issue in medicine. Cave related diseases can occur, leading to serious health problems for the tourists. Sometimes, the visitors to the cave might come in contact with pathogens in the cave, resulting in cave associated infections. In this short article, the authors hereby summarize and discuss cave associated infections with special reference to tropical countries. There are many possible cave associated infections, such as histoplasmosis and rabies, which are considered serious health problems. ${ }^{1}$

\section{Cave related health problems}

As already mentioned, there are some diseases that are associated with visiting a cave. The explanation for the existence of cave associated disease is clarified by the principle of epidemiology. Regarding the epidemiological triad, the host is hereby the human. The agents might be dangerous things in the cave, toxic animals, microbial, etc. The environment is the cave cavity. When the human and the causative agent live at the same place and at the same time in the cave cavity, the disease might occur. Several factors might promote the occurrence of cave associated disease, as mentioned in Table 1. Simply, the chance of disease occurrence increases when there is increased contact in terms of the amount and period of time.

Of interest, the problem of cave associated disease is usually seen in long-term cave visitors, such as cavern researchers or trapped victims. Cave associated diseases might be physical or psychological. In this short article, the authors hereby will focus discussion on specific groups of cave associated disease and cave associated infection.
Table 1 Factors relating to the occurrence of cave related disease

\begin{tabular}{ll}
\hline Factors & Examples \\
\hline Host factor & $\begin{array}{l}\text { Immunity, physical fitness, age, underlying } \\
\text { disease, drug and alcohol use } \\
\text { Virulence, toxicity, power } \\
\text { Enent factor }\end{array}$ \\
$\begin{array}{l}\text { Moisture, steepness, air flow, humidity, } \\
\text { sharpness }\end{array}$ \\
\hline
\end{tabular}

\section{Important cave associated infections}

\section{A. Viral infection}

Several viruses can be seen in the cave atmosphere. The cave visitor might come into contact with the virus directly or through contact with an animal vector. The most serious disease is rabies. Cave bats are proven reservoir hosts for the rabies virus, and visiting caves is considered risky behavior due to any possible contact with a rabid bat. ${ }^{2}$ In tropical countries, the risk of bat rabies should be considered. In a study among frequent cave visitors in Thailand, bat bites are not uncommon, and visitors usually lack knowledge regarding bat rabies. ${ }^{3}$

In addition, some caves in tropical countries might be transformed and modified into religious places, such as pagodas. In these cases, buildings in the city style might exist at the cave. Mosquitos might reside in the buildings and might transmit some mosquito borne viral infectious diseases, such as dengue. ${ }^{4}$

\section{B. Fungal infection}

Many caves are humid and this might promote the growth of fungi, including pathogenic fungi. The most well-known cave related fungal infection is histoplasmosis. The outbreak of histoplasmosis in cave visitors is well documented in medical literature. Pathogenic fungi can be 
detected in bat caves and might infect anyone who visits the cave., ${ }^{5,6}$ The soil in the bat cave in tropical countries is usually contaminated with pathogenic fungi. ${ }^{7}$ According to the report by Ashford et al., patients usually have bronchitis or pneumonia. ${ }^{5}$ The patient might develop clinical problems several months after the cave visit. ${ }^{6}$ Ashford et al. noted that cave visitors should be given information related to histoplasmosis as a precaution. ${ }^{5}$

\section{Bacterial infection}

Several bacteria including bacterial pathogens colonize the cave and the cave visitor might come in contact with these problematic bacteria. For example, if the visitor falls in the cave, the visitor might get a wound and might further develop a tetanus infection. In addition, the visitor might directly come in contact with a serious disease, such as melioidosis, due to inhalation of the pathogens. Also, the visitor might get leptospirosis due to contact with contaminated water in the cave. ${ }^{1}$ The increased $\mathrm{pH}$ of water in the cave is mentioned as an important factor in increasing the risk of infection. ${ }^{8}$

\section{Parasitic infection}

Finally, the chance of the cave visitor getting malaria due to a mosquito bite in the cave is possible. According to a recent report, the mosquito vector can be seen in the cave and might transmit some mosquito borne diseases, such as filariasis or malaria, to the cave visitor. This is an important but forgotten issue in travel and tropical medicine.

\section{Implication for public health}

Searching for cave associated infections is an important issue in the medical care of the patients who have unexplained illnesses and a history of visiting caves. Sometimes, the short-term cave visitor might get a disease. For example, the mosquito in the cave might bite a cave visitor and transmit an infectious disease. Also, it is a requirement to check the health of long-term cave visitors. A complete health screening for victims trapped in a cave must also cover the possible infections that might come from the cave. In fact, the well-known situation of the victims trapped in Tham Laung Nangnorn cave in Thailand, which was reported in the global news, is a good example. After rescuing the victims from the cave, a close monitoring of them in the hospital was required. This included monitoring the victims for possible cave related infections.

From the viewpoint of preventive medicine, suggestions for tourists regarding cave-related diseases are important. Safety procedures and infectious disease prevention must be included in any consultation for travelers. In the case of traveling to tropical countries, specific information regarding tropical diseases must also be given to travelers.

\section{Conclusion}

There are many possible cave associated infections. Disease is sporadically reported in cave visitors. To manage patients with illness and a history of visiting caves, it is necessary to recognize cave associated infection.

\section{Conflict of interest}

None

\section{References}

1. Igreja RP. Infectious diseases associated with caves. Wilderness Environ Med 2011;22:115-21.

2. Mehal JM, Holman RC, Brass DA, Blanton JD, Petersen BW. Changes in knowledge of bat rabies and human exposure among United States cavers. Am J Trop Med Hyg 2014;90: 263-4.

3. Robertson K, Lumlertdacha B, Franka R, Petersen B, Bhengsri $S$, Henchaichon S, et al. Rabies-related knowledge and practices among persons at risk of bat exposures in Thailand. PLoS Negl Trop Dis 2011;5:e1054. 
4. Adam JP. Transmission of hemosporidia by Anopheles cavenicolus in the cave of the Congo (Brazaville). Bull World Health Organ 1965;32:598-60.

5. Ponnampalam J. Isolation of histoplasma capsulatum from the soil of a cave in central Malaya. Am J Trop Med Hyg 1963; $12: 775-6$.

6. Ashford DA, Hajjeh RA, Kelley MF, Kaufman L, Hutwagner L, McNeil MM. Outbreak of histoplasmosis among cavers attending the National Speleological Society Annual Convention, Texas, 1994. Am J Trop Med Hyg 1999;60:899903.

7. Lottenberg R, Waldman RH, Ajello L, Hoff GL, Bigler W, Zellner SR. Pulmonary histoplasmosis associated with exploration of a bat cave. Am J Epidemiol 1979;110:156-61.

8. Mortimer RB. Leptospirosis in a caver returned from Sarawak, Malaysia. Wilderness Environ Med 2005;16:129-31. 